GRASAS Y ACEITES 66 (3)

July-September 2015, e086

ISSN-L: 0017-3495

doi: http://dx.doi.org/10.3989/gya.1062142

\title{
Carotenoid composition in oils obtained from palm fruits from the Brazilian Amazon
}

\author{
M.F.G. Santos ${ }^{\mathrm{a}}$, R.E. Alves ${ }^{\mathrm{b}}$, and M. Roca ${ }^{\mathrm{c}, \bowtie}$ \\ ${ }^{a}$ Instituto de Pesquisas Científicas e Tecnológicas do Amapá. Rodovia JK, 10, 68900-000, Macapá-AP, Brazil \\ ${ }^{b}$ Embrapa Agroindustria Tropical.Dra. Sara Mesquita, 2270, Pici, 60511-110, Fortaleza-CE, Brazil \\ 'Instituto de la Grasa-CSIC. Pablo de Olavide University Campus, Bldg. 46, Carretera de Utrera Km. 1, 41013 Seville-Spain \\ ${ }^{\otimes}$ Corresponding author: mroca@ig.csic.es
}

Submitted: 08 October 2014; Accepted: 10 February 2015

SUMMARY: The oils obtained from native palm fruits are considered new sources of high added value phytochemicals, making it necessary to know the composition of the less studied species in order to evaluate their economic potential. The objective of this study is to identify and quantify the carotenoids in palm fruit oils from the Brazilian Amazon: bacaba (Oenocarpus bacaba), buriti (Mauritia flexuosa), inajá (Maximiliana maripa), pupunha (Bactris gasipaes) and tucumã (Astrocaryum vulgare), by means of liquid phase extraction and HPLC-UV-vis. analysis. The results showed an extremely variable carotenoid content, from $13 \mathrm{mg} \cdot \mathrm{kg}^{-1}$ in bacaba oil to more than $1000 \mathrm{mg} \cdot \mathrm{kg}^{-1}$ in the tucumã one. The oils obtained from buriti, pupunha and tucumã displayed high concentrations of $\beta$-carotene, corresponding to fruits with the series $B, \beta$ dominant metabolism. Upon analyzing the carotenoid profile in bacaba oil for the first time, an extraordinary dominance of the $B, \varepsilon$ pathway was observed, proving them to be oils with high lutein and $\alpha$-carotene contents. Although the $\beta, \beta$ pathway dominates in inajá oil, the exclusive and high lycopene content implies that LCY-E is barely active in these fruits, in contrast to what has been evidenced so far. It is therefore of the utmost importance to characterize these new potential sources of carotenoids.

KEYWORDS: Astrocaryum vulgare; Bactris gasipaes; HPLC-carotenoids; Mauritia flexuosa; Maximiliana maripa; Oenocarpus vacaba; Palm oils

RESUMEN: Composición de carotenoides en aceites obtenidos a partir de frutos de palma de la Amazonia Brasileña. Los aceites obtenidos a partir de frutos de palmeras nativas son considerados nuevas fuentes de fitoquímicos con alto valor añadido siendo necesario conocer la composición de las especies menos exploradas para evaluar su potencial económico. El objetivo de este estudio es identificar y cuantificar los carotenoides en aceites defrutos de palmeras provenientes de la Amazonia Brasileña: bacaba (Oenocarpus bacaba), buriti (Mauritia flexuosa), inajá (Maximiliana maripa), pupunha (Bactris gasipaes) y tucumã (Astrocaryum vulgare), mediante extracción líquido:líquido y análisis por HPLC-UV-vis. Los resultados mostraron un contenido de carotenoides muy variable, entre $13 \mathrm{mg} \cdot \mathrm{kg}^{-1}$ en el aceite de bacaba y superior a $1000 \mathrm{mg} \cdot \mathrm{kg}^{-1}$ en el aceite de tucumá. Los aceites procedentes de buriti, pupunha y tucumã presentaron altas concentraciones de B-caroteno, correspondiendo a frutos con metabolismo dominante de la serie $\beta, B$. Al analizar por primera vez el perfil carotenoides del aceite de bacaba se observó una excepcional dominancia de la ruta $\beta, \varepsilon$, y consecuentemente presenta un alto contenido en luteína y $\alpha$-caroteno. Aunque en los aceites de inajá predomina la ruta $\beta, \beta$, el exclusivo y alto contenido de licopeno implica que LCY-E es muy poco activa en estos frutos, a diferencia de lo descrito hasta el momento. Resulta pues fundamental caracterizar estas nuevas potenciales fuentes de carotenoides.

PALABRAS CLAVE: Aceites de palma; Astrocaryum vulgare; Bactris gasipaes; HPLC-carotenoides; Mauritia flexuosa; Maximiliana maripa; Oenocarpus vacaba

Citation/Cómo citar este artículo: Santos MFG, Alves RE, Roca M. Carotenoid composition in oils obtained from palm fruits from the Brazilian Amazon. Grasas Aceites 66 (3): e086. doi: http://dx.doi.org/10.3989/gya.1062142.

Copyright: (C) 2015 CSIC. This is an open-access article distributed under the terms of the Creative Commons Attribution-Non Commercial (by-nc) Spain 3.0 Licence. 


\section{INTRODUCTION}

In recent years, there has been great interest in the oils obtained from fruits. Amongst the contributing reasons for this are that they can be directly consumed without the need for refining (olives, avocadoes, palms) due to their extraction system, and their nutritional properties, considering the appropriate composition of fatty acids, sterols, carotenoids and antioxidants (Clement, 2005). Some of the species that have attracted attention, not only for their lipid contents but also for their bioactive compound compositions such as sterols, tocopherols and carotenoids are: bacaba (Oenocarpus bacaba Mart), buriti (Mauritia flexuosa L.f.), inajá (Maximiliana maripa (Corrêa), Drude), pupunha (Bactris gasipaes Kunth) and tucumã (Astrocaryum vulgare Mart). All of them are used as raw materials for oil extraction for use in the food and cosmetic industries (Santos et al., 2013).

Due to their chemical composition, the oils obtained from native palm fruits are considered new sources of high-added-value phytochemicals, since studies developed on certain species have shown that they have significant phytochemicals, such as unsaturated fatty acids, phytosterols, tocopherols and $\beta$-carotene, among others (Yuyama et al., 2003; Bereau et al., 2003; Rosso and Mercadante, 2007; Rodrigues et al., 2010; Mantúfar et al., 2010; VázquezOcmín et al., 2010).

Carotenoids, found in vegetable oils, have antioxidant and anti-carcinogenic properties (Anjo, 2004; Uenojo et al., 2007). According to Ambrósio et al. (2006), $\beta$-carotene is a powerful antioxidant which protects against cardiovascular diseases once it has inhibited the oxidation process of low-density lipoproteins (LDL).

Due to the beneficial properties of carotenoids and their high quantitative levels in palm fruits, their identification and quantification has been performed in the mesocarp of several species (buriti, pupunha and tucumã) (Rodríguez-Amaya et al. 2008; De Rosso and Mercadante 2007). However, the oils extracted from palm fruits have only been characterized spectrophotometrically for their total carotenoid content (Mambrine et al., 1997, Ferreira et al., 1999; Fihlo et al., 2013), and these have been considered as potential sources of carotenoids (Manorama et al., 1991; Rodriguez-Amaya, 1996). In fact, the enrichment of foods with natural sources of $\beta$-carotene, such as these palm oils, could be an alternative solution to preventing the hypo-vitaminosis A disorder in Brazilian population (Ambrosio et al., 2006).

During the oil extraction process, the original carotenoid profile from fruit tissue undergoes chemical modifications (Roca and Mínguez-Mosquera, 2003). The transfer of carotenoids to the oil can mean transformation, degradation, concentration and/or selective transfer reactions of the carotenoids themselves (for example increasing the content in lutein, or generating new carotenoids such as mutatoxanthin or luteoxanthin due to the acidic $\mathrm{pH}$ during the extraction in olive oils). Therefore, it is necessary to identify and quantify the carotenoids present in the oils of palm fruits. The objective of this study is to identify and quantify the carotenoids in palm fruit oils obtained from the Brazilian Amazon.

\section{MATERIALS AND METHODS}

\subsection{Materials}

Samples of fruits from five palm species, i.e. bacaba (Oenocarpus bacaba), buriti (Mauritia flexuosa), inajá (Maximiliana maripa), pupunha (Bactris gasipaes) and tucumã (Astrocaryum vulgare), were collected in the State of Amapá, Brazil. The mesocarp of the fruits was separated, moisture was eliminated by freeze-drying before lipid extraction and lyophilized samples were maintained at $-30^{\circ} \mathrm{C}$ until extraction and analysis.

\subsection{Carotenoid extraction}

The total amount of lipids in the samples was determined by Soxhlet extraction with an extraction period of $6 \mathrm{~h}$ and diethyl ether as solvent (AENOR, 1991). Then, the solvent was evaporated under vacuum and the extracted oil was dried to constant weight using a stream of nitrogen.

The samples were dissolved in different amounts of acetone depending on the total carotenoid concentration that they showed in previous tests. $1.5 \mathrm{~mL}$ was used for bacaba, $5 \mathrm{~mL}$ for inajá and $10 \mathrm{~mL}$ for buriti, pupunha and tucumã. One $\mathrm{mL}$ aliquot of the solution was centrifuged at $12000 \mathrm{rpm}$ and stored at $-30{ }^{\circ} \mathrm{C}$ until analysis. All analyses were carried out in triplicate and under diminished light.

\subsection{Isolation of carotenoid standards for HPLC}

$\beta$-Carotene, lutein, $B$-cryptoxanthin, lycopene and $\alpha$-carotene were supplied by Sigma-Aldrich Chemical Co. (Madrid, Spain). Violaxanthin, neoxanthin, anteraxanthin, $\delta$-carotene and $\gamma$-carotene were supplied by Carote Nature (Lupsingen, Switzerland). Luteoxanthin and mutatoxanthin were obtained by acidification with $1 \mathrm{M} \mathrm{HCl}$ in ethanol (Khachik et al., 1986), purified by NP- and RP-TLC (MínguezMosquera et al., 1991).

\subsection{Analysis of carotenoids by HPLC}

The samples were analysed using a Hewlett Packard HP 1100 HPLC model, with a stainless steel column $(20 \times 0.46 \mathrm{~cm}$ I.D. $)$, packed with a $\mathrm{C} 18$ solid phase $3 \mu \mathrm{m}$ particle size (Mediterranea Sea, Teknokroma, 
Barcelona, Spain). The column was protected by a pre-column $(1 \times 0.4 \mathrm{~cm}$ I.D. $)$ packed with the same material. The separation was performed using a gradient (flow $1.25 \mathrm{~mL} \cdot \mathrm{min}^{-1}$ ) with the mobile phases: water/ion pair/methanol $(1 / 1 / 8, \mathrm{v} / \mathrm{v} / \mathrm{v})$ and methanol/acetone $(1 / 1, \mathrm{v} / \mathrm{v})$. The ion pair was $0.05 \mathrm{M}$ tetrabutylammonium and $1 \mathrm{M}$ ammonium acetate in water (Mínguez-Mosquera et al., 1991). A photodiode array detector was used for detection, registering the signal between $350 \mathrm{~nm}-800 \mathrm{~nm}$, although the quantification was performed between $430 \mathrm{~nm}-450 \mathrm{~nm}$, depending on the maximum absorption of the carotenoids. The data were processed using the LCHP ChemStation software (Rev.A.05.04). The pigments were measured from their respective calibration curves (quantity versus integrated peak area). The calibration equations were derived from the linear regression analysis of least squares, in ranges of concentration in line with carotenoid levels in the respective oils. For each standard solution, five different volumes were prepared and injected twice.

\subsection{Carotenoid identification}

This has been described in detail in previous publications, Mínguez-Mosquera and Hornero-Méndez (1993), and consist of the following procedures: separation and isolation of the pigment by TLC and co-chromatography with standard pigments; observation of the pigment color on TLC plates under white, $\mathrm{UV}_{254} \mathrm{~nm}$, and $\mathrm{UV}_{360} \mathrm{~nm}$ lights; acquisition of UV-visible spectrain different solvents and comparison of the maximum(s) with the values reported in the literature; chemical derivatization microscale tests. For 5,8 epoxi-carotene, $\delta$-carotene and $\gamma$-carotene, the identification was made only on the basis of their spectroscopic characteristics (Rodriguez-Amaya, 1996; de Rosso et al., 2007).

\subsection{Statistical Analysis of Data}

All experiments were carried out in triplicate. Data were expressed as mean values \pm SD. The SD was lower than $10 \%$. The data were analyzed for significant differences among means using one way analysis of variance (ANOVA). Duncan's multiplerange test was used as a post hoc comparison of statistical significance ( $\mathrm{p}$ values $<0.05$ ). All statistical analyses were performed using Statistica for Windows (version 5.1, StatSoft, Inc., Tulsa, OK).

\section{RESULTS AND DISCUSSION}

The characteristics of the carotenoids identified in the analyzed oil samples are detailed in Table 1. The identification is based on their chromatographic

TABlE 1. Chromatographic and spectroscopic characteristics of carotenoids from different Brazilian palm oils

\begin{tabular}{|c|c|c|c|c|c|c|}
\hline \multirow[b]{2}{*}{ Peak } & \multirow[b]{2}{*}{ Carotenoid } & \multirow[b]{2}{*}{ Retention time } & \multicolumn{3}{|c|}{ Position of peak (nm) } & \multirow{2}{*}{$\begin{array}{l}\text { Peak height } \\
\text { relationship } \\
\text { (100III/II) }\end{array}$} \\
\hline & & & I & II & III & \\
\hline 1 & neoxanthin & 5.48 & 414 & 438 & 466 & 90 \\
\hline 2 & violaxanthin & 6.51 & 417 & 440 & 471 & 94 \\
\hline 3 & luteoxanthin & 6.99 & 405 & 426 & 450 & 90 \\
\hline 4 & cis violaxanthin & 7.29 & 417 & 436 & 470 & 92 \\
\hline 5 & antheraxanthin & 7.89 & 425 & 446 & 474 & 22 \\
\hline 6 & mutatoxanthin & 8.02 & 404 & 425 & 451 & 39 \\
\hline 7 & lutein & 9.05 & 424 & 446 & 474 & 60 \\
\hline 8 & cis lutein & 9.92 & 422 & 442 & 471 & 30 \\
\hline 9 & cis $\delta$ carotene & 16.03 & 432 & 458 & 488 & 35 \\
\hline 10 & $\beta$-cryptoxanthin & 16.49 & 431 & 452 & 479 & 25 \\
\hline 11 & $\delta$ carotene & 17.13 & 430 & 452 & 475 & 46 \\
\hline 12 & 5,8 epoxy $\beta$-carotene & 21.27 & 410 & 434 & 456 & \\
\hline 13 & cis lycopene & 23.36 & 442 & 468 & 500 & 87 \\
\hline 14 & lycopene & 23.88 & 450 & 476 & 508 & 91 \\
\hline 15 & cis $\gamma$ carotene & 25.30 & 438 & 460 & 492 & 46 \\
\hline 16 & $\gamma$ carotene & 25.87 & 435 & 463 & 499 & 57 \\
\hline 17 & cis $\alpha$-carotene & 26.15 & 418 & 442 & 470 & 40 \\
\hline 18 & $\alpha$-carotene & 26.78 & 424 & 448 & 476 & 57 \\
\hline 19 & cis $\beta$-carotene & 27.73 & 420 & 448 & 478 & 14 \\
\hline 20 & $\beta$-carotene & 27.78 & 432 & 454 & 481 & 26 \\
\hline
\end{tabular}


and spectroscopic properties, as well as the cochromatography of the corresponding standards. All the identified carotenoids were in free form as in previous reports (Rodriguez-Amaya, 1996; de Rosso et al., 2007), a peculiar fact due to the high content of oils of these fruits. Other oil-rich fruits, such as olives, have shown a similar profile without esterified carotenoids (Mínguez-Mosquera et al., 1992).

The detailed carotenoid composition of the oils extracted from the mesocarp of palm fruits found in the Brazilian Amazon can be found in Table 2. We can observe that the carotenoid content is highly variable, between $13 \mathrm{mg} \cdot \mathrm{kg}^{-1}$ in the case of bacaba oil and more than $1000 \mathrm{mg} \cdot \mathrm{kg}^{-1}$ for tucumã oil. The existing studies on fruit comparison among different species describe buriti as the most concentrated source of carotenoids (Rodriguez-Amaya, 1996; de Rosso et al., 2007). However, our results show that the concentration of carotenoids in the respective oils is far greater in those from the tucumã mesocarp. This fact can be explained by several factors: the variability and/or ripening stage of the analyzed fruits, the region of provenance and a greater or lesser extent of the extraction procedure.

Generally, the palm fruits studied until now are rich in B-carotene (Rodriguez-Amaya, 1996; de Rosso et al., 2007), as the B, B pathway domains (Figure 1) during carotenoid synthesis, as is the case in the oils obtained from buriti, pupunha and tucumã. The dominance of the $\beta, \beta$ series in fruits is transferred to the respective oils in these varieties, as can be observed in Table 2, where the carotenoid profile is dominated by $\beta$-carotene. However, from the analysis of the carotenoid profile present in bacaba and inajá oils, achieved for the first time in this study, a significant metabolic deviation from the previous general pattern can be observed. The results obtained from this work show that palm fruits where the $\beta, \varepsilon$ pathway is dominant also exist, as it is the case in oils found in bacaba, due to the high content of lutein and $\alpha$-carotene. Inajá oils are equally interesting. Although the $B, B$ pathway prevails here, the exclusive and high content of lycopene implies that LCY-E is barely active in these fruits, in contrast to the evidence provided until now.

A detailed analysis by species shows that bacaba is the oil with the lowest measured total carotenoid content (Table 2 and Figure 2). A similar trend was reported by Mambrimand Barrera-Arellano (1997). However, in contrast to the other palm fruits, it is highly interesting as it is a fruit mainly made up of xanthophylls $(65 \%)$, a significant feature not previously recorded in the literature. Within xanthophylls, lutein is the main carotenoid (57\%), followed by luteoxanthin, mutatoxanthin and antheraxanthin (Figure 1) that reach up to $3 \%$. Luteoxanthin and mutatoxanthin are derivatives of violaxanthin and antheraxanthin, respectively,

TABLE 2. Carotenoid composition ( $\mathrm{mg} \cdot \mathrm{kg}^{-1}$ oil) of different Brazilian palm oils

\begin{tabular}{lccccc}
\hline Carotenoids & bacaba & buriti & inajá & pupunha & tucumã \\
\hline neoxanthin & - & - & - & - & $76.08 \pm 6.72$ \\
violaxanthin & $0.17 \pm 0.01$ & - & - & - & $13.53 \pm 0.57$ \\
luteoxanthin & - & $2.68 \pm 0.17$ & - & - & $16.13 \pm 0.88$ \\
cis violaxanthin & - & - & - & - & $12.80 \pm 0.92$ \\
antheraxanthin & $0.11 \pm 0.01$ & - & - & - & - \\
mutatoxanthin & $0.17 \pm 0.01$ & - & - & - & - \\
lutein & $6.20 \pm 0.35$ & $32.12 \pm 2.38$ & - & $11.94 \pm 0.17$ & $44.34 \pm 1.44$ \\
cis lutein & $1.78 \pm 0.11$ & $16.28 \pm 1.07$ & - & $2.22 \pm 0.19$ & $12.57 \pm 0.12$ \\
cis $\delta$-carotene & - & - & - & $1.64 \pm 0.09$ & - \\
$\beta$-cryptoxanthin & $0.18 \pm 0.01$ & - & - & - & $14.43 \pm 1.31$ \\
$\delta$-carotene & - & - & - & $3.07 \pm 0.29$ & - \\
5,8 epoxy $\beta$-carotene & - & $4.38 \pm 0.24$ & - & - & $27.25 \pm 2.69$ \\
cis licopene & - & - & $15.49 \pm 0.62$ & $26.84 \pm 1.60$ & - \\
licopene & - & - & $15.33 \pm 1.36$ & $30.8 \pm 0.54$ & - \\
cis $\gamma$ carotene & - & $1.82 \pm 0.08$ & $9.81 \pm 0.35$ & $35.40 \pm 0.61$ & $75.87 \pm 5.54$ \\
$\gamma$ carotene & - & $3.45 \pm 0.29$ & $14.85 \pm 0.74$ & $67.62 \pm 0.30$ & $68.02 \pm 3.44$ \\
cis $\alpha$-carotene & $0.16 \pm 0.01$ & $1.8 \pm 0.08$ & - & - & - \\
$\alpha$-carotene & $1.05 \pm 0.08$ & $19.20 \pm 1.69$ & $0.51 \pm 0.03$ & - & $29,21 \pm 2.62$ \\
cis $\beta$-carotene & $0.70 \pm 0.05$ & $165.65 \pm 14.64$ & $6.01 \pm 0.59$ & $27.66 \pm 2.13$ & $230.92 \pm 14.50$ \\
$\beta$-carotene & $3.02 \pm 0.28$ & $295.24 \pm 17.89$ & $23.03 \pm 1.59$ & $150.19 \pm 3.90$ & $567.08 \pm 25.29$ \\
TOTAL (mg $\cdot k g-1)$ & $13.53 \pm 0.97$ & $540.81 \pm 36.09$ & $85.03 \pm 6.30$ & $357.42 \pm 3.85$ & $1222.33 \pm 34.50$ \\
\hline
\end{tabular}




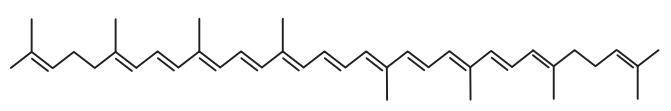

all-trans-lycopene

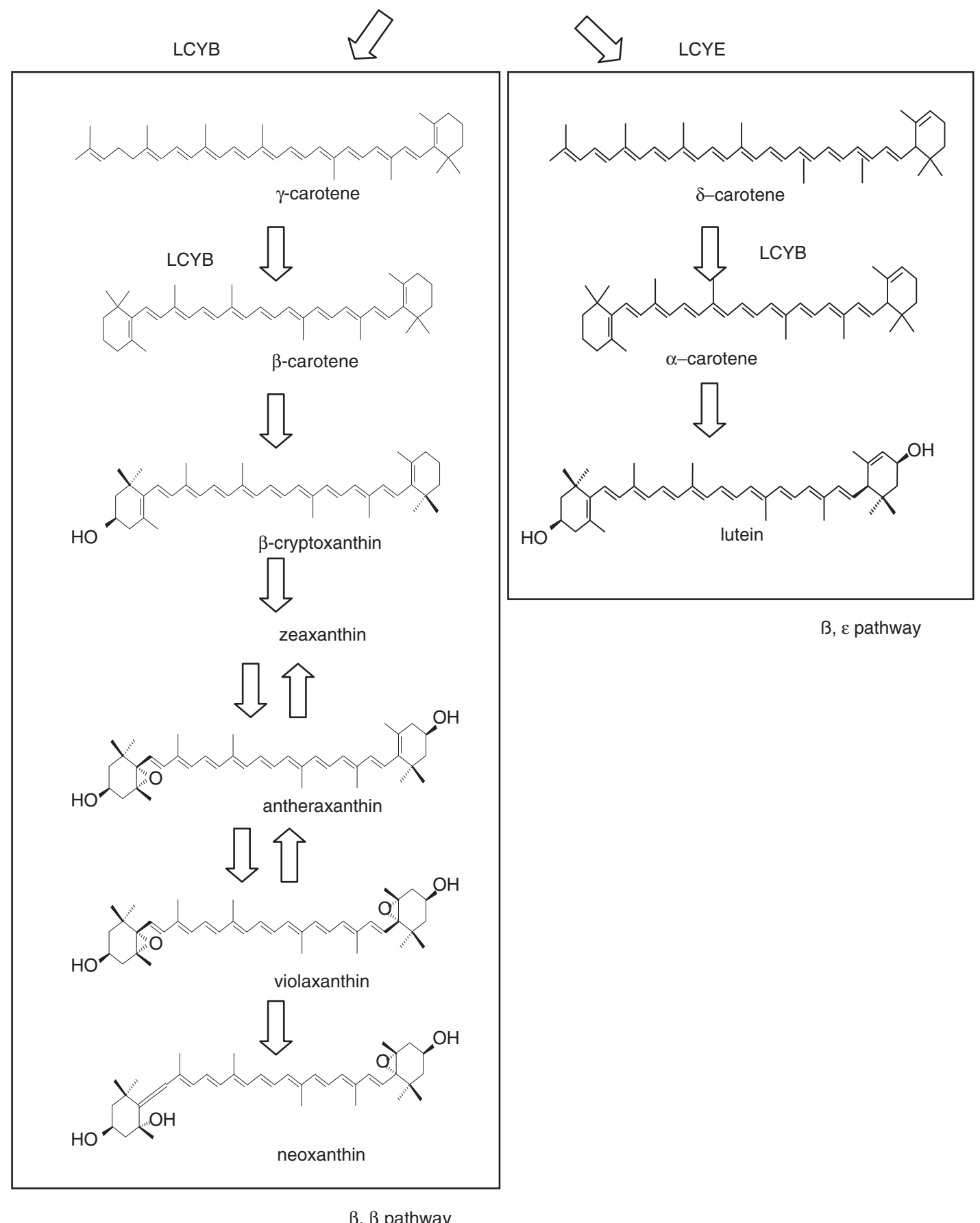

$\beta, \beta$ pathway

FiguRE 1. Scheme of carotenoid biosynthesis from lycopene.

through the transformation of the 5,3 epoxide group in 5, 8 furanoid. This modification is typical during the oil extraction process (Roca and Mínguez-Mosquera,
2003) due to the release of acid material from the vegetal tissue. $\beta$ and $\alpha$-carotene are the main components found within the carotene fraction. 
The profile and content of inajá oil described in Table 2 and Figure 3 are completely new, as only the total carotenoid value, around $150 \mathrm{mg} \cdot \mathrm{kg}^{-1}$ found within the dry pulp of fruits has previously been published (Telles, 2006), which are similar to those values obtained in this study (Table 2). The high proportion of lycopene in its oil (33\%) is a significant novelty in palms oils with a content of $30 \mathrm{mg} \cdot \mathrm{kg}^{-1}$ that fits with that found in papaya or watermelon (Perkins-Veazie et al., 2006; Souza et al., 2008). Similar values have been quantified for $\beta$-carotene, the carotene that is most present in this oil, followed by $\gamma$-carotene and $\alpha$-carotene.

There are not literature reports on the carotenoid content of pupunha oil but, taking into account the quantities reported for the pulp of this fruit (between $1 \mathrm{mg}-20 \mathrm{mg} \cdot 100 \mathrm{~g}^{-1}$ ) (Rosso and Mercadante, 2007; Rodríguez-Amaya et al., 2008; Jatunov et al., 2010) and its low lipid content (Santos et al., 2013), we can calculate carotenoid concentrations within theoretic oils to be similar to those obtained in Table 2. The carotenoid profile obtained from the oil matches that recorded for the pulp of these fruits (Rosso and Mercadante, 2007; Rodríguez-Amaya et al. 2008), where $B$-carotene dominates, together with lower values of $\gamma$-carotene and $\delta$-carotene.

The total carotenoid content in the oil from buriti fruits is detailed in the literature is highly variable, fluctuating between $600 \mathrm{ppm}$ and 10,000 ppm (Ferreira et al., 2011, Ferreira et al., 1999), probably depending on the varietial selection, the degree of ripeness, agronomical factors, and extraction procedure. However, the carotenoid profiles obtained from the corresponding oils is equivalent to that obtained in the mesocarp of its fruits (Rosso and Mercadante, 2007), with $85 \%$ of the fraction dominated by $B$-carotene, the reason for which this oil is used as a source of pro-vitamin A.

Oils obtained from tucumã pulp show a greater carotenoid content (above $1000 \mathrm{ppm}$ ) with these values being similar to those detailed in the literature (Mambrini et al., 1997). The carotenoid profile is dominated by the high content of $\beta$-carotene, which is higher than $60 \%$ of the total fraction, a value that is in contrast to the high content in the carotenoid found in the pulp of these fruits (Rosso and Mercadante, 2007; Rodríguez-Amaya et al. 2008). Recently, a study has shown the genoprotective effects against the DNA of tucumã oil's (DNA fragmentation, Comet assay, and chromosomal instability G-band assays) (Fihlo et al., 2013). The authors justified the results obtained in relation to the high concentration of antioxidant compounds, mainly $\beta$-carotene of this fruit. Particularly interesting is the presence of neoxanthin and violaxanthin (together with its derivative luteoxanthin) in those oils, as this feature differentiates it from other palm fruits. These xanthophylls are the final derivatives of the $B, B$ pathway, a dominant cycle in tucumã fruits.

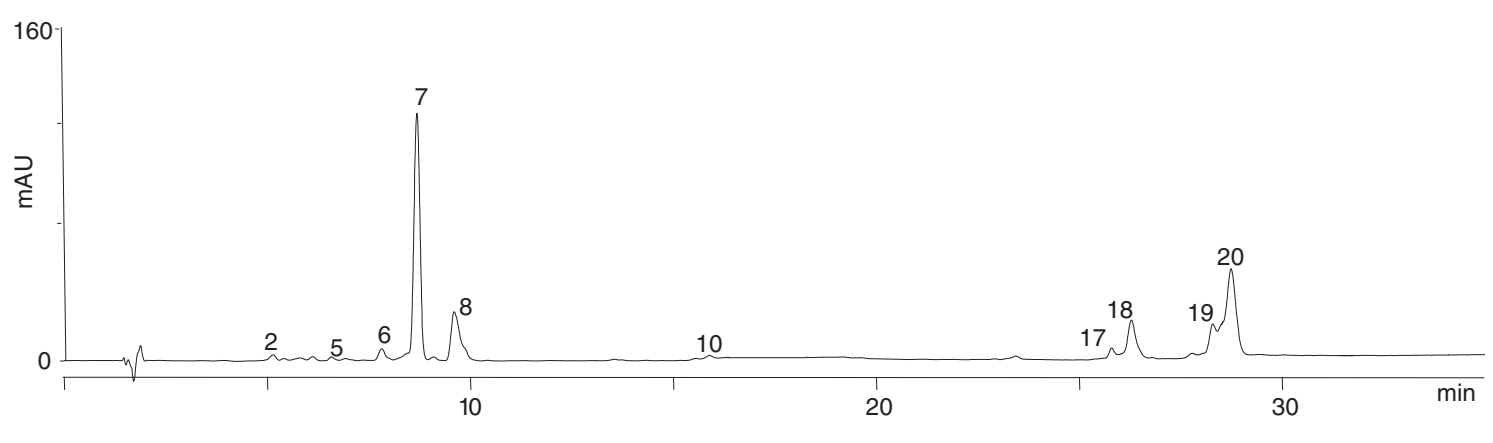

FIgURE 2. HPLC chromatogram at $450 \mathrm{~nm}$ of the carotenoids from bacaba palm oils. Peak numbers as in Table 1.

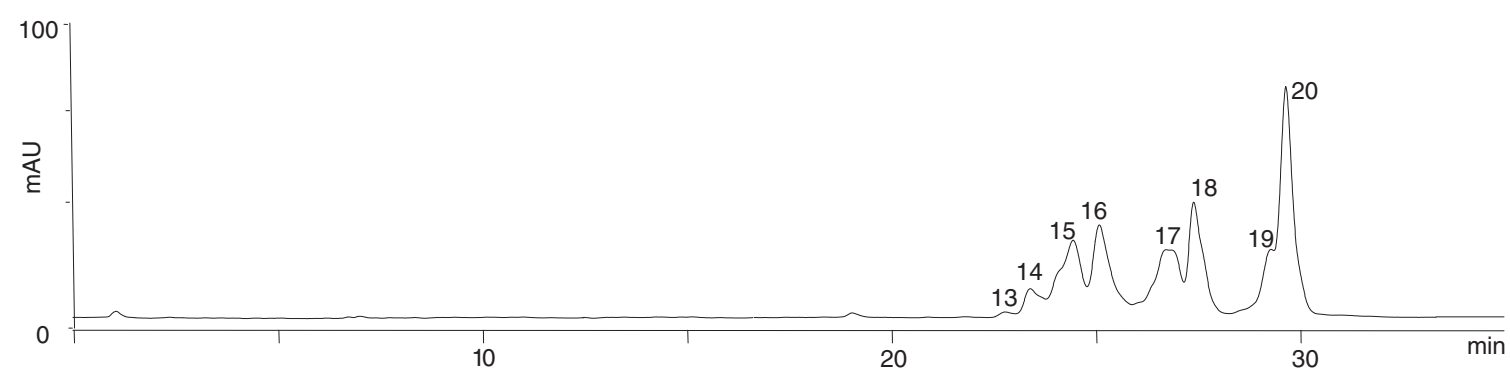

FIGURE 3. HPLC chromatogram at $450 \mathrm{~nm}$ of the carotenoids from inajá palm oils. Peak numbers as in Table 1 


\section{CONCLUSIONS}

The analysis of the carotenoid content in oils from different types of palm show highly variable amounts, with pupunha, buriti and tucumã containing the highest contents from the analyzed species in this work. Moreover, the properties of these species are dominated by a high content of $B$-carotene, meaning that their intake has a highadded value of pro-vitamin A. Inajá oils are characterized by a high content of lycopene, while those from bacaba present exceptionally strengthened $B$, $\varepsilon$ synthesis pathway, which is rarely predominant in palm fruits. To the promising nutritional value of Inajá and bacaba palm oils this report combines biochemical interest as the carotenogenesis develops under a different pathway generally accepted for palm fruits.

\section{ACKNOWLEDGMENTS}

The authors would like to thank the Coordinación de Perfeccionamiento de Personal de Nivel SuperiorCAPES, for the foreign doctoral fellowship to Mary Santos. Thanks are due to Sergio Alcañiz-García for his technical assistance. This work was supported by the Comisión Interministerial de Ciencia y Tecnología (CICYT-EU, Spanish and European Government, AGL 2012-39714) and by Junta de Andalucía (AGR 6271-2011). This work has been developed under the IBERCAROT Project (Red Iberoamericana para el estudio de nuevos carotenoides bioactivos como ingredientes de alimentos- P111RT0247-CYTED).

\section{REFERENCES}

AENOR (1991) Norma UNE 55-062-80 para la determinación del materias grasas en semillas oleaginosas. Catálogo de Normas UNE, Madrid.

Ambrosio CLB, Campos FACS, Faro ZP. 2006. Carotenóides como alternativa contra a hipovitaminose A. Revista Nutrição 19, 233-243. http://dx.doi.org/10.1590/S141552732006000200010.

Anjo DLC. 2004. Alimentos funcionais em angiologia e cirurgia vascular. J. Vascular Brasileiro, 3, 145-154.

Bereau D, Benjelloun-Mlayah B, Banoub J, Bravo R. 2003. FA and unsaponifiable composition of five Amazinian palm kernel oils. J. Am. Oil Chem. Soc. 80, 49-53. http://dx.doi. org/10.1007/s11746-003-0649-5.

Clement CR, Lleras Pérez E, Van Leeuwen J. 2005. O potencial das palmeiras tropicais no Brasil: acertos e fracassos das últimas décadas. Agrociências 9, 67-71.

Ferreira BS, Almeida CG, Faza LP, Almeida A, Diniz AG, Silva VC, Grazul RM, Le Hyaric M. 2011. Comparative Properties of Amazonian Oils Obtained by Different Extraction Methods. Molecules 16, 5875-5885. http:// dx.doi.org/10.3390/molecules16075875.

Ferreira de Franc L, Reber G, Meireles AA, Machado NT, Brunner G. 1999. Supercritical extraction of carotenoids and lipids from buriti (Mauritia flexuosa), a fruit from the Amazon region. J. Supercrit. Fluids, 14, 247-256. http:// dx.doi.org/10.1016/S0896-8446(98)00122-3.

Filho OCS, Sagrillo MR, Garcia LFM, Machado AK, Cadona F, Ribeiro EE, Duarte EEMF, Morel AF, da Cruz IVM. 2013. The In Vitro Genotoxic Effect of Tucuma (Astrocaryum aculeatum), an Amazonian Fruit Rich in
Carotenoids. J. Medicinal Food, 16, 1013-1021. http:// dx.doi.org/10.1089/jmf.2012.0287.

Jatunov S, Quesada S, Díaz C, Murillo E. 2010. Carotenoid composition and antioxidant activity of the rawand boiled fruit mesocarp of six varieties of Bactris gasipaes. Arch. Latinoam. Nutr. 60, 99-104.

Khachik F, Beecher GR, Whittaker NF. 1986. Separation, identification, and quantification of themajor carotenoid and chlorophyll constituents inextracts of several green vegetables by liquid chro-matography. J. Agric. Food Chem. 34, 603-616. http://dx.doi.org/10.1021/jf00070a006.

Mambrin MCT, Barrera-Arellano D. 1997. Caracterización de aceites de frutos de palmeras de la región amazonica del Brasil. Grasas Aceites 48, 154-158. http://dx.doi.org/ 10.3989/gya.1997.v48.i3.783.

Manorama R, Rukmini C. 1991. Effect of processing on $\beta$-carotene retention in crude palm oil and its products. Food Chem. 42, 253-264. http://dx.doi.org/10.1016/03088146(91)90068-Y.

Souza LM, Ferreira KS, Chaves JBP, Teixeira SL. 2008. L-Ascorbic acid, $\beta$-carotene and lycopene content in papaya fruits (Carica papaya) with or without physiological skin freckles. Sci. Agric. 65, 246-250.

Mínguez-Mosquera MI, Gandul-Rojas B, Montaño-Asquerino A, Garrido-Fernández J. 1991. Determination of chlorophylls and carotenoides by HPLC during olive lactic fermentation. J. Chromatogr. 585, 259-266. http://dx.doi.org/ 10.1016/0021-9673(91)85086-U.

Mínguez-Mosquera MI, Gandul-Rojas B, Gallardo-Guerrero L. 1992. Rapid method of quantification of chlorophylls ands carotenoides in virgin olive oil by HPLC. J. Agric. Food Chem. 40, 60-63. http://dx.doi.org/10.1021/jf00013a012.

Mínguez-Mosquera MI, Hornero-Méndez D. 1993. Separation and quantification of the carotenoid pigments in red peppers (Capsicumannum L.), paprika, and oleoresin by reversed-phase HPLC. J. Agric. Food Chem. 41, 1616-1620. http://dx.doi.org/10.1021/jf00034a018.

Montúfar R, Laffargue A, Pintaud J, Hamon S, Avallone S, Dussert S. 2010. Oenocarpus bataua Mart. (Arecaceae): rediscovering a source of high oleic vegetable oil from Amazonia. J. Am. Oil Chem. Soc. 87, 167-172. http:// dx.doi.org/10.1007/s11746-009-1490-4.

Perkins-Veazie P, Collins JK, Davis AR, Roberts W, 2006. Carotenoid content of 50 watermelon cultivars. J. Agric. Food Chem. 54, 2593-2597. http://dx.doi.org/10.1021/ jf052066p.

Roca M, Mínguez-Mosquera MI. 2003. Carotenoid levels during the period of growth and ripening in fruits of different olive varieties (Hojiblanca, Picual and Arbequina). J. Plant Physiol. 160, 451-459. http://dx.doi.org/10.1078/ 0176-1617-00759.

Rodrigues AMC, Darnet S, Silva LHM. 2010. Fatty Acid profiles tocopherol of buriti (Mauritia flexuosa), patawa (Oenocarpus bataua), tucuma (Astrocaryum vulgare), mari (Poraqueiba paraensis) and inajá (Maximiliana maripa) fruits. J. Braz. Chem. Soc. 21, 2000-2004. http://dx.doi. org/10.1590/S0103-50532010001000028.

Rodriguez-Amaya DB. 1996. Assessment of the Provitamin A Contents of Foods-The Brazilian Experience. J. Food Compos. Anal. 9, 196-230. http://dx.doi.org/10.1006/jfca. 1996.0028.

Rodriguez-Amaya DB, Kimura M, Godoy HT, Amaya-Farfan J. 2008. Updated Brazilian database on food carotenoids: Factors affecting carotenoidcomposition. J. Food Compos. Anal. 21, 445-463. http://dx.doi.org/10.1016/j.jfca.2008. 04.001 .

Rosso VV, Mercadante AZ. 2007. Identification and quantification of carotenoides, by HPLC-PDA-MS/MS, from Amazonian fruits. J. Agric. Food Chem. 55, 5062-5072. http://dx.doi.org/10.1021/jf0705421.

Santos MFG, Marmesat S, Brito ES, Alves RE, Dobarganes MC. 2013. Major components in oils obtained from Amazonian palm fruits. Grasas Aceites 64, 328-334. http://dx.doi.org/ $10.3989 /$ gya. 023513 .

Telles M. 2006. Determinação de tocoferóis e carotenóides emfrutas amazônicas: Implantação de uma metodologia. 
Tesis Doctoral. Universidade Federal do Pará, Centro Tecnológico,Ciência e Tecnologia de Alimentos, Belém.

Uenojo M, Maróstica Junior MR, Pastore GM. 2007. Carotenóides: propriedades, aplicações e biotransformação para formação de compostos de aroma. Química Nova 30, 616-622. http:// dx.doi.org/10.1590/S0100-40422007000300022.

Vásquez-Ocnín PG, Alvarado LF, Solís VC, Torres RP, ManciniFilho J. 2010. Chemical characterizacion and oxidative stability of the oils from three morphotypes of Mauritia flexuosa L. f, from the Peruvian Amazon. Grasas Aceites 61, 390-397. http://dx.doi.org/10.3989/gya.010110.

Yuyama LKO, Aguiar JPL, Yuyama K, Clement CR, Macedo SHM, Fávaro DIT, Afonso C, Vasconcellos MBA, Pimentel SA, Badolato ESG, Vannucchi H. 2003. Chemical composition of the fruit mesocarp of three peach palm (Bactris gasipaes) populations grown in central Amazonia, Brazil. Int. J. Food Sci. Nutr. 54, 49-56. http://dx.doi.org/10.1080/ 0963748031000061994 